\title{
The African contribution to the global climate-carbon cycle feedback of the 21 st century
}

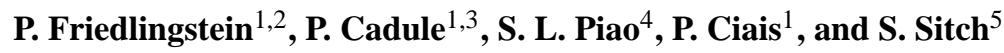 \\ ${ }^{1}$ IPSL/LSCE, UMR 1572 CEA-CNRS, CEA-Saclay, L'Orme des Merisiers, 91191 Gif-sur-Yvette, France \\ ${ }^{2}$ QUEST, Department of Earth Sciences, University of Bristol, Bristol BS8 1RJ, UK \\ ${ }^{3}$ IPSL, 4 place Jussieu, 75252 Paris, France \\ ${ }^{4}$ Department of Ecology, Peking University, Beijing 100871, China \\ ${ }^{5}$ School of Geography, University of Leeds, Leeds LS2 9JT, UK
}

Received: 1 September 2008 - Published in Biogeosciences Discuss.: 10 December 2008

Revised: 10 December 2009 - Accepted: 22 December 2009 - Published: 8 February 2010

\begin{abstract}
Future climate change will have impact on global and regional terrestrial carbon balances. The fate of African tropical forests over the 21 st century has been investigated through global coupled climate carbon cycle model simulations. Under the SRES-A2 socio-economic $\mathrm{CO}_{2}$ emission scenario of the IPCC, and using the Institut Pierre Simon Laplace coupled ocean-terrestrial carbon cycle and climate model, IPSL-CM4-LOOP, we found that the warming over African ecosystems induces a reduction of net ecosystem productivity, making a $38 \%$ contribution to the global climate-carbon cycle positive feedback. Most of this contribution comes from African grasslands, followed by African savannahs, African tropical forest contributing little to the global climate-carbon feedback. However, the vulnerability of the African rainforest ecosystem is quite large. In contrast, the Amazon forest, despite its lower vulnerability, has a much larger overall contribution due to its 6 times larger extent.
\end{abstract}

\section{Introduction}

Coupled climate carbon cycle studies highlighted the vulnerability of the continental biosphere to human induced climate change (Cox et al., 2000; Dufresne et al., 2002). In particular tropical forest ecosystems may play a key role in future changes in global carbon balance. These ecosystems represent the largest reservoir of living biomass. The balance

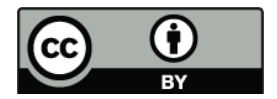

Correspondence to: P. Friedlingstein (pierre.friedlingstein@1sce.ipsl.fr) between carbon uptake through photosynthesis and release from decomposition of organic matter is sensitive to changes in climate regime, such as increased aridity. Climate variability and rising $\mathrm{CO}_{2}$ have also an impact on tropical forest biomass growth rates and mortality (Clark et al., 2003), and on $\mathrm{CO}_{2}$ emissions related to fire disturbances (Nepstad et al., 2004). There is a consensus among the coupled climate carbon cycle models to simulate a decrease of terrestrial carbon uptake in the tropics under future climate change (Friedlingstein et al., 2006, hereafter F06). This decreased tropical land uptake is a dominant contributor to the positive carbon cycle - climate feedbacks found in coupled models. Its causes have to be found in a combination of reduced photosynthesis due to a warming, generally combined with an increase in soil aridity, as well as an increase in soil oxidation, due to the warming. Some models also simulate a decrease of forest density, and a gradual replacement by savannah type ecosystems.

On shorter time scales, such as the interannual variability, recent studies also highlighted the dominant role of tropical ecosystem in the control of atmospheric $\mathrm{CO}_{2}$ growth rate (e.g. Rodenbeck et al., 2003; Peylin et al., 2005; Baker et al., 2006). The El Niño/Southern Oscillation (ENSO) climate variability induces large excursions in photosynthesis and/or decomposition and fires (Page et al., 2002) leading to anomalous $\mathrm{CO}_{2}$ release from tropical ecosystems during El Niño events, and conversely to anomalous uptake during the cooler and wetter La Niña episodes. However, the effect of drought in decreasing $\mathrm{C}$ uptake as simulated by all global models, was recently challenged by field measurements showing locally more $\mathrm{C}$ uptake by tropical forests during the dry periods (Saleska et al., 2007; Bonal et al., 2008).

Published by Copernicus Publications on behalf of the European Geosciences Union. 
However, so far, within the tropical forest, most of the focus has been given to the Amazon basin (Cox et al., 2004; Betts et al., 2004; Huntingford et al., 2004). For example, the fate of the Amazon forest has been largely investigated, as this ecosystem show a very strong positive feedback, i.e., carbon release, through its dieback in the Hadley Centre future climate-carbon simulations (Cox et al., 2000, 2004). Also the Large-Scale Biosphere - Atmosphere Experiment in Amazonia (LBA) program (http://lba.inpa.gov.br/lba) provided ecosystem and atmospheric data that were used by models in order to gain process understanding of the Amazon forest. Oppositely, very few studies focused on the African tropical forest and savannas biomes, their role in the global present carbon cycle and its vulnerability to future climate change.

\section{Methodology}

In a companion paper (Ciais et al., 2008), we used the ORCHIDEE global land ecosystem model (Krinner et al., 2005) forced by the observed evolution of the climate of the 20th century to investigate the present and historical African carbon balance. Here, we used the same land surface model, ORCHIDEE, but embedded within the Atmosphere Ocean General circulation model of IPSL in order to simulate the past and future evolution of the climate and carbon cycle. The IPSL-CM4-LOOP model couples the ocean-atmosphere general circulation model IPSL-CM4 (Dufresne et al., 2007) and the land and ocean carbon cycle models, ORCHIDEE (Krinner et al., 2005) and PISCES (Aumont and Bopp, 2006).

Following the coupled climate carbon cycle model intercomparison project (C4MIP) protocol described in F06, we performed two climate-carbon coupled simulations (UNC and COU) over the 1860-2100 period. In both experiments, $\mathrm{CO}_{2}$ emissions are prescribed from historical data for 1860-2000 (Marland et al., 2005; Houghton and Hackler, 2002) and from the SRES-A2 scenario for the 21 st century (Nakićenović, et al., 2000). The other greenhouse gas concentrations are set to pre-industrial values. Land cover was prescribed in all simulations. COU and UNC differ because in $\mathrm{UNC}, \mathrm{CO}_{2}$ is treated as a non-radiatively active gas, so that the carbon cycle experiences no $\mathrm{CO}_{2}$-induced climate change. The difference between these two runs defines the climate carbon cycle feedback. We note that the UNC simulation does still simulate a moderate warming. This is due to the stomatal response to increasing atmospheric $\mathrm{CO}_{2}$, which leads to a shift from latent to sensible heat release from the surface, as reported before (e.g. Sellers et al., 1996).

\section{Results}

The global results of the IPSL-CM4-LOOP model have been described in previous papers (F06, Cadule et al., 2010).
Here we will shortly summarize the main performance of the model. The COU simulation leads to a global surface warming of $3.7 \mathrm{~K}$ by 2100 and an atmospheric $\mathrm{CO}_{2}$ concentration of $807 \mathrm{ppm}$. The UNC simulation, with no climate change, leads to a $\mathrm{CO}_{2}$ concentration of $776 \mathrm{ppm}$, The difference, i.e. $31 \mathrm{ppm}$, is due to a decrease of both land and ocean carbon uptake under future climate conditions. The cumulated land sinks decreases by $80 \mathrm{PgC}$ while the ocean sinks decrease by $65 \mathrm{PgC}$ between 1901 and 2100.

When compared to the other C4MIP models, IPSL-CM4LOOP has a lower than the average climate carbon cycle feedback. The $\mathrm{CO}_{2}$ amplification, $31 \mathrm{ppm}$, translates in a gain of $6 \%$, where the C4MIP models show an average amplification of $85 \mathrm{ppm}$, that is, an average gain is $15 \%$. This low gain cannot be explained by the climate sensitivity of the climate model as it is on the higher end of the C4MIP models. It is rather a direct result of the low sensitivity of the land carbon cycle to the climate change (called $\gamma_{L}$ in F06). We defined $\gamma_{L}$ as the difference in cumulated NEP in COU and UNC (corrected by the effect of atmospheric $\mathrm{CO}_{2}$ difference between the two simulations), normalized by the surface temperature change between COU and UNC (see F06 and Friedlingstein et al., 2003 for details). In other words, $\gamma_{L}$ describes the sensitivity of the land carbon cycle to warming. In IPSL-CM4-LOOP, $\gamma_{L}$ amounts to $-20 \mathrm{PgC} \mathrm{K}^{-1}$, where the C4MIP models average is $-80 \mathrm{PgC} \mathrm{K}^{-1}$. ORCHIDEE simulates a climate induced reduction of Net Ecosystem Productivity (NEP) in the tropics but largely balanced by an increased NEP in mid and high latitudes ecosystems. This positive NEP response is partly due to a cold bias in the UNC climate of the model in these regions.

Over Africa, the model simulates a regional warming by the end of the 21 st century. This warming amounts to $3 \mathrm{~K}$ in the Congo basin, but reaches $6 \mathrm{~K}$ in South Africa and in northern Sahel (Fig. 1). The associated change in precipitation is an increase in precipitation around the equator (up to $300 \mathrm{~mm} \mathrm{yr}^{-1} ;+20 \%$ ) and a reduction in precipitation outside of the tropical belt (up to $100 \mathrm{~mm} \mathrm{yr}^{-1}$ ) (Fig. 1). The regions with more warming also experience drying, while regions (Central Africa) which warm moderately experience wetter conditions in the future. These results are consistent with the ones obtained by the IPCC 4th Assessment Report climate models for the SRES-A2 scenario (see Fig. 11.2 of IPCC Working Group 1, 4th Assessment Report, Christensen et al., 2007). This climate change pattern is rather similar to the conditions of a permanent El Niño episode over the African continent (see Ciais et al., 2010).

When looking at the carbon cycle, the Gross Primary Productivity (GPP) of the COU coupled run increases everywhere across Africa, the largest increase being, as could be expected, in the already most productive regions of the African rainforest (Fig. 2). Overall GPP increases from $25 \mathrm{PgC} \mathrm{yr}^{-1}$ at pre-industrial up to $40 \mathrm{PgC} \mathrm{yr}^{-1}$ by 2100 . Across the tropical rainforest ecosystem, this increase is a essentially driven by a GPP enhancement by atmospheric $\mathrm{CO}_{2}$ 

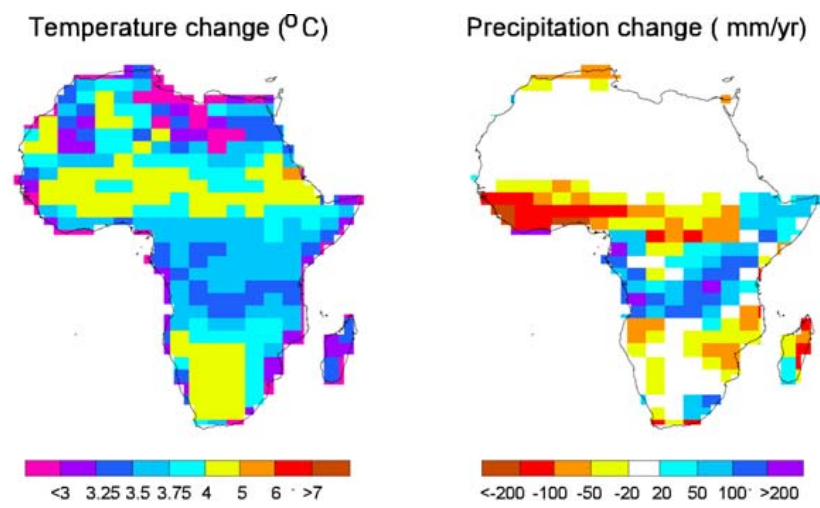

Fig. 1. Climate change (2090s relative to 1860s) simulated with the IPSL-CM4-LOOP coupled model over Africa. Left panel is for surface temperature change $\left({ }^{\circ} \mathrm{C}\right)$, right panel is for precipitation changes $\left(\mathrm{mm} \mathrm{yr}^{-1}\right)$.

(fertilization). Climate change has a small negative impact on the GPP of the African continent. Indeed, when looking at the difference between the coupled and the uncoupled runs, which allow to isolate the climate effect of the carbon

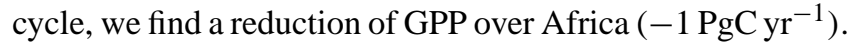
This climate induced change in GPP varies widely within African ecosystems. The ORCHIDEE model uses a Plant Functional Type (PFT) approach to represent the different types of ecosystems. In order to further analyze the model results we separate the contribution from African forests (defined as the model grid cells where the tree PFTs fraction is above 0.66), African savannahs (tree PFTs fraction between 0.33 and 0.66 ) and African grasslands (tree PFTs fraction below 0.33). Doing so, we estimate that forests show a 5\% increase in GPP, savannahs show no significant changes and grasslands show a 10\% decrease in GPP (Fig. 3). Although we do not focus on cropland here, as there representation in the model is quite crude; they do also show a decrease of GPP.

Net carbon exchange (NEP) is reduced when climate change is taken into account (Fig. 3). The total African NEP cumulated over $1860-2100$ amounts to $72 \mathrm{PgC}$ in the $\mathrm{COU}$ run while it reaches $129 \mathrm{PgC}$ in UNC (Fig. 4). The NEP reduction is much larger than the one of GPP because of a concomitant increase of total respiration under climate change. Autotrophic and especially heterotrophic respiration shows an important increase due to the regional warming (Fig. 3).

In term of reservoirs, total living biomass increases over the 1860-2100 period in Africa, largely thanks to the $\mathrm{CO}_{2}$ fertilization of productivity. Total biomass increases from 60 to $115 \mathrm{PgC}$ in the uncoupled simulation. Climate change tends to reduce that increase but only marginally $(-3 \mathrm{PgC})$. The soil carbon response to climate change is much larger. The large increase in heterotrophic respiration leads to a soil carbon loss of $54 \mathrm{PgC}$ (in simulation COU relative to simulation UNC).

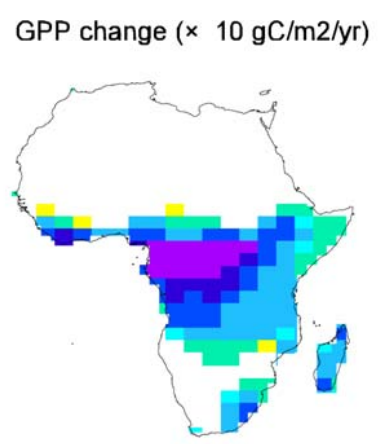

NPP change ( $\times 10 \mathrm{gC} / \mathrm{m} 2 / \mathrm{yr})$

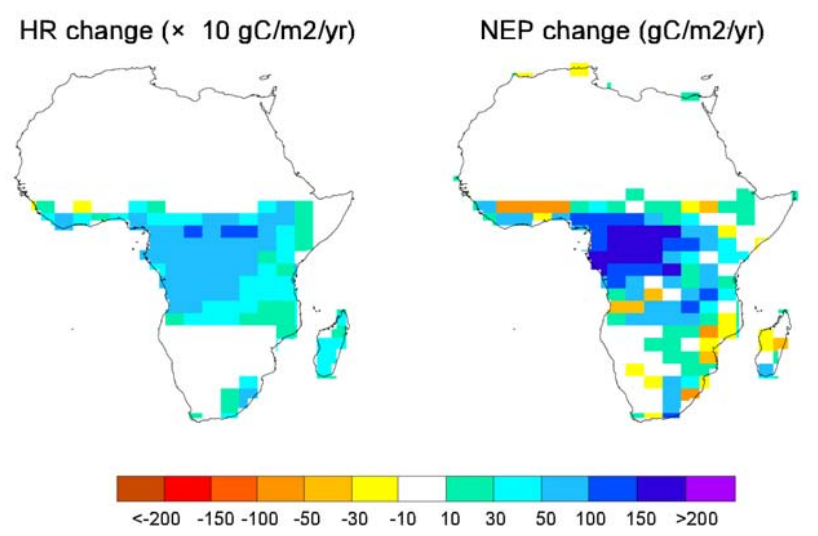

Fig. 2. Carbon fluxes change (2090s relative to 1860s) from IPSLCM4-LOOP coupled simulation (COU) over Africa. Top left panel is for Gross Primary Productivity, top right panel is for Net Primary productivity, bottom left panel is for Heterotrophic Respiration, and bottom right is for Net Ecosystem Productivity (all in $\mathrm{gC} \mathrm{m}^{-2} \mathrm{yr}^{-1}$ ). Note that first three quantities have to be multiplied by 10 .

A cumulated release of $57 \mathrm{PgC}$ to the atmosphere would translate into an increase in concentration of about $12 \mathrm{ppmv}$, assuming an airborne fraction of 0.45 . The African carbon response to climate change represents then about $38 \%$ of the global feedback of the IPSL-CM4-LOOP model (31 ppm). When looking at dominant natural biomes (defined here at tropical forest, savannahs and grasslands) the model simulate a carbon loss from all biomes (Fig. 4). The contribution from the African tropical forest alone is only $4 \mathrm{PgC}$, which translates into about $1 \mathrm{ppm}$, i.e. as very small contribution to the global feedback. African savannahs contribute to $18 \mathrm{PgC}$ $(4 \mathrm{ppm})$ and natural grasslands have the largest share, $34 \mathrm{PgC}$ (7 ppm) (Table 1).

We note that the relative climate-carbon feedbacks are not simply additive as some regions, such as the high latitudes of the Northern Hemisphere have a negative contribution to the overall positive feedback.

Also the relative contributions of the African biomes should be weighted by their spatial coverage. Grasslands are by far the most dominant natural biome in Africa, followed by savannahs, and by forest. In order to better compare the 
GPP change $(\mathrm{gC} / \mathrm{m} 2 / \mathrm{yr})$
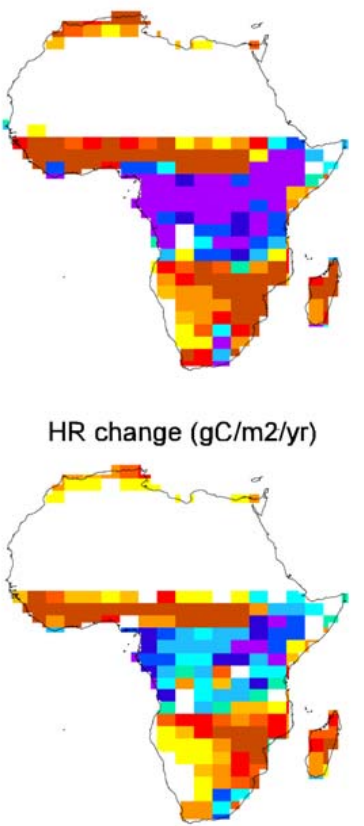

Biomass change $(\times \quad 10 \mathrm{gC} / \mathrm{m} 2)$

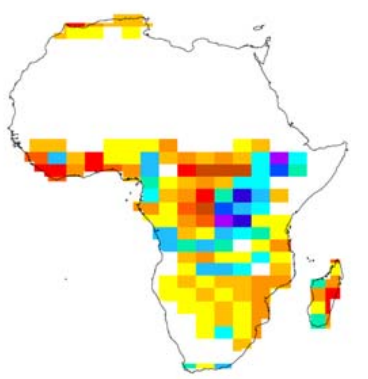

NPP change $(\mathrm{gC} / \mathrm{m} 2 / \mathrm{yr})$

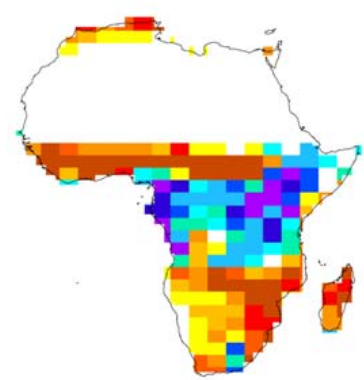

NEP change $(\mathrm{gC} / \mathrm{m} 2 / \mathrm{yr})$

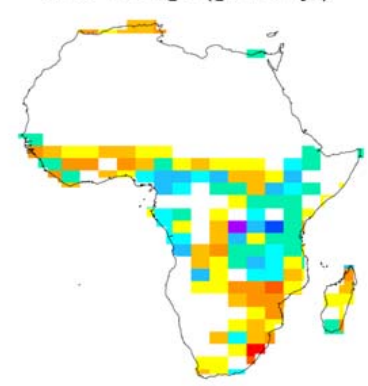

Soil $\mathrm{C}$ change (× $10 \mathrm{gC} / \mathrm{m} 2)$

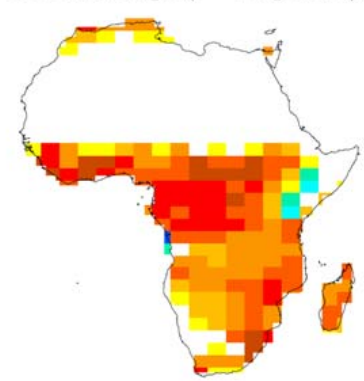

(a)

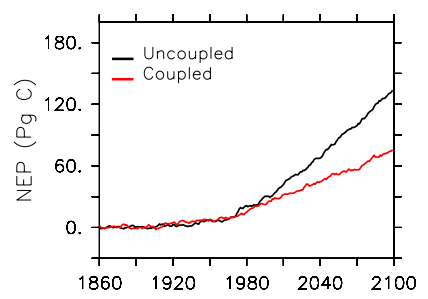

(c)

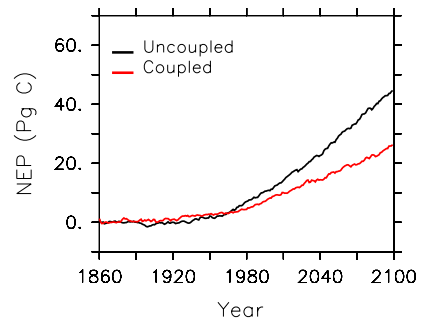

(b)

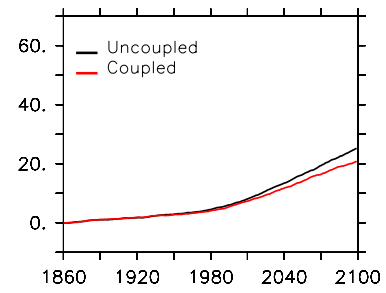

(d)

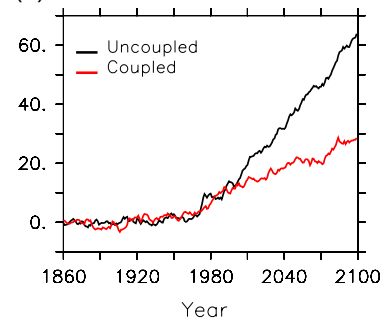

Fig. 4. Time evolution of cumulated change in NEP from IPSLCM4-LOOP coupled (in black) and uncoupled (in red) simulations over (a) the Africa continent, (b) the African rainforest, (c) the African savannah, and (d) the African grasslands. Units are PgC.

Doing so, we estimate that African forest and savannahs have very similar $\bar{\gamma}_{L},-950 \mathrm{gC} \mathrm{m}^{-2} \mathrm{~K}^{-1}$ and $-980 \mathrm{gC} \mathrm{m}^{-2}$ $\mathrm{K}^{-1}$ respectively, while African grasslands are much more resilient, with a $\bar{\gamma}_{L}$ of $-290 \mathrm{gC} \mathrm{m}^{-2} \mathrm{~K}^{-1}$ only. The large contribution of African grasslands to the overall positive feedback comes from the larger spatial coverage of that biome, despite its lower area specific vulnerability.

\section{Discussion}

Doing a similar calculation of the carbon loss from the Amazon forest shows that in the IPSL-CM4-LOOP model, the Amazon forest gives a much larger contribution than the African rain forest, $15 \mathrm{PgC}$ reduction of $1860-2100$ cumulated NEP in COU relative to UNC (Fig. 5). Again, this larger contribution comes from the area of the domain considered. The area of the Amazon basin is four times larger than the African rainforest basin. Also, in the Amazon, the carbon loss is largely driven by the reduction of GPP due to the increased aridity. A climatic pattern sometimes referred as a "perpetual El Niño". In Africa, during such "perpetual El Niño" the precipitation pattern is drastically different with an enhancement of precipitation over tropical rain forest and a reduction over already more arid regions (north equatorial and southern African savannas). In the African rainforest, as explained above, the carbon loss only comes then from an enhanced respiration due to the warming trend.

We also estimate the area specific carbon vulnerability to climate, $\bar{\gamma}_{L}$ for the Amazon forest. It amounts to $-640 \mathrm{gC} \mathrm{m}^{-2} \mathrm{~K}^{-1}$, a value actually slightly 
Table 1. Change in Net Ecosystem Productivity and associated area specific carbon vulnerability over Africa, African forest, savannah and grasslands and Amazon tropical forest.

\begin{tabular}{lcccc}
\hline & $\begin{array}{c}\text { Cumulated } \\
\text { NEP Coupled } \\
\text { run (PgC) }\end{array}$ & $\begin{array}{c}\text { Cumulated } \\
\text { NEP Uncoupled } \\
\text { run (PgC) }\end{array}$ & $\begin{array}{c}\text { Climate } \\
\text { induced NEP } \\
\text { reduction }(\mathrm{PgC})\end{array}$ & $\begin{array}{c}\bar{\gamma}_{L} \\
\left(\mathrm{gC} \mathrm{m}^{-2} \mathrm{~K}^{-1}\right)\end{array}$ \\
\hline Africa & 72 & 129 & 57 & -600 \\
African rainforest & 20 & 24 & 4 & -950 \\
African savannah & 25 & 43 & 18 & -980 \\
African grassland & 28 & 62 & 34 & -290 \\
Amazon rainforest & 41 & 56 & 15 & -640 \\
\hline
\end{tabular}

(a)

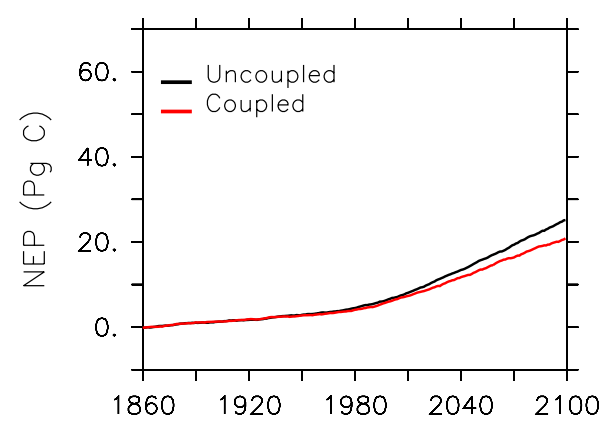

(b)

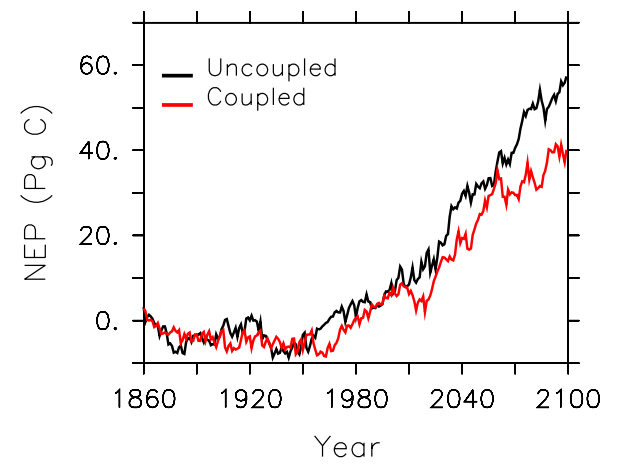

Fig. 5. As Fig. 4 for (a) the African rainforest, and (b) the Amazon basin. Units are $\mathrm{PgC}$.

less negative than the one obtained for the Amazon forest $\left(-950 \mathrm{gC} \mathrm{m}^{-2} \mathrm{~K}^{-1}\right)$ (Table 1). Again, the larger contribution of the Amazon forest to the global climate carbon feedback is entirely driven by its larger spatial extension, not by its specific vulnerability.

It should be noted that these results are directly dependent on the climate change simulated by the climate model. Although changes in temperature are relatively robust at the regional scale, including in the tropics, the same does not hold for changes in precipitations (Christensen et al., 2001). For example, the Hadley Centre model simulates a mush
Temperature change $\left({ }^{\circ} \mathrm{C}\right)$

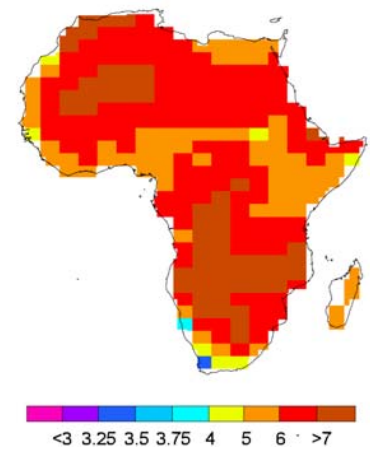

Precipitation change ( $\mathrm{mm} / \mathrm{yr})$

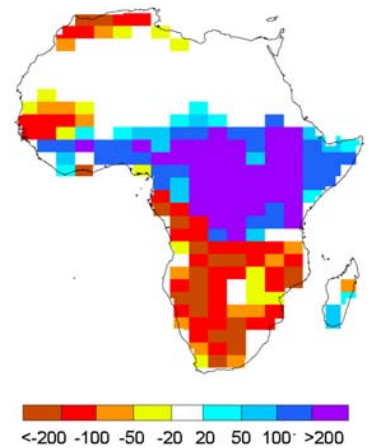

Fig. 6. Climate change (2090s relative to 1860 s) simulated by the HadCM3-LC climate model. As in Fig. 1, left panel is for surface temperature change $\left({ }^{\circ} \mathrm{C}\right)$, right panel is for precipitation changes $\left(\mathrm{mm} \mathrm{yr}^{-1}\right)$.

stronger than IPSL precipitation reduction over the Amazon rainforest, associated with a twice as larger warming (Fig. 6). For African rainforest basin both models simulate similar changes in temperature and precipitation. Land response would then be dramatically different for the Amazon basin, while being comparable for the African rainforest.

Also, the modeling framework used here has some important limitations in term of process representation. Nitrogen cycle and its impact on terrestrial carbon cycle were not accounted for here. A recent study with a nitrogen enabled version of ORCHIDEE (Zaehle et al., 2010) shows that nitrogen limitation reduces $\mathrm{CO}_{2}$ fertilization but increases photosynthesis under global warming, although these effects are mainly active in the mid and high latitudes, and would not dramatically affect our results over Africa. Natural fires were accounted here, but with a relatively simple global fire model. More elaborate fire models are being developed now and the response of fires to climate variability and trends (e.g. VanderWerf et al., 2004; Golding and Betts, 2008) imply that fires are certainly important players in the future carbon budget of the tropics. 


\section{Conclusions}

Tropical ecosystems will be put at risk over the coming century, due to climate change, but also due to the direct anthropogenic pressure, through deforestation (not accounted for in this study). In the coupled carbon climate simulations that we analyzed, the African continent would gain carbon by the end of the 21 st century (relative to preindustrial, thanks to the fertilization effect from the atmospheric $\mathrm{CO}_{2}$ increase. However, the associated climate change tends to reduce this African storage by $25 \%$, from $129 \mathrm{PgC}$ to $72 \mathrm{PgC}$. The African continent is hence an active player of the climate-carbon cycle positive feedback, with a contribution of about $38 \%$ of the global feedback of the IPSL-CM4LOOP model.

Although usually pointed as the major carbon source, South America tropical forests have a lower contribution than the African savannahs or African grasslands. However, when looking at the tropical rain forest ecosystem alone, although their specific vulnerability is slightly larger for African forests, the overall contribution from Africa is much lower than the one from South America because of its much smaller area. Altogether, more than $50 \%$ of the feedback comes from Africa and South America in the IPSLCM4-LOOP simulations. Finally, we note that there is still a large uncertainty in the climate response of African vs. Amazon rainforests due to the uncertainty of climate projections, especially the hydrological cycle at the regional scale.

Acknowledgements. This paper is the outcome of the CarbonClimate-Human Interactions in Africa symposium organized by the Global Carbon Project (GCP). The study was supported by European Community-funded projects ENSEMBLES and CARBOEUROPE IP, and by the National Natural Science Foundation of China. The computer time was provided by Commissariat à l'Energie Atomique (CEA).

Edited by: A. Arneth

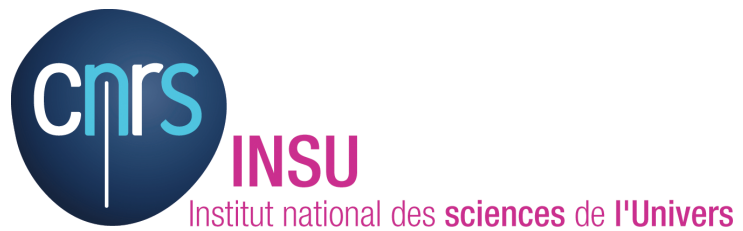

The publication of this article is financed by CNRS-INSU.

\section{References}

Aumont O. and Bopp, L.: Globalizing results from ocean in situ iron fertilization studies, Global Biogeochem. Cy., 20, GB2017, doi:10.1029/2005GB002591, 2006.

Baker, D. F., Law, R. M., Gurney, K. R., Rayner, P., Peylin, P., Denning, A. S., Bousquet, P., Bruhwiler, L., Chen, Y.-H., Ciais, P., Fung, I. Y., Heimann, M., John, J., Maki, T., Maksyutov,
S., Masarie, K., Prather, M., Pak, B., Taguchi, S., and Zhu, Z.: TransCom 3 inversion intercomparison: Impact of transport model errors on the interannual variability of regional $\mathrm{CO}$ 2 fluxes, 1988-2003, Global Biogeochem. Cy., 20, GB1002, doi:10.1029/2004GB002439, 2006.

Betts, R. A., Cox, P. M., Collins, M., Harris, P. P., Huntingford, C., and Jones, C. D.: The role of ecosystem-atmosphere interactions in simulated Amazonian precipitation decrease and forest dieback under global climate warming, Theor. Appl. Climatol., 78, 157-175, 2004.

Bonal, D., Bosc, A., Ponton, S., Goret, J.-Y., Burban, B., Gross, P.,, Bonnefond, J.-M., Elbers, J., Longdoz, B., Epron, D., Guehl, J.M., and Granier, A.: Impact of severe dry season on net ecosystem exchange in the Neotropical rainforest of French Guiana, Glob. Change Biol., 14, 1917-1933, 2008.

Cadule, P., Friedlingstein, P., Bopp, L., Sitch, S., Jones, C. D., Ciais, P., Piao, S. L., and Peylin, P.: Benchmarking coupled climatecarbon models against long-term atmospheric $\mathrm{CO}_{2}$ measurements, Global Biogeochem. Cy., doi:10.1029/2009GB003556, in press, 2010.

Christensen, J. H., Hewitson, B., Busuioc, A., Chen, A., Gao, X., Held, I., Jones, R., Kolli, R. K., Kwon, W.-T., Laprise, R., Magaña Rueda, V., Mearns, L., Menéndez, C. G., Räisänen, J., Rinke, A., Sarr, A., and Whetton, P.: Regional Climate Projections, in: Climate Change 2007: The Physical Science Basis. Contribution of Working Group I to the Fourth Assessment Report of the Intergovernmental Panel on Climate Change, edited by: Solomon, S., Qin, D., Manning, M., Chen, Z., Marquis, M., Averyt, K. B., Tignor, M., and Miller, H. L., Cambridge University Press, Cambridge, United Kingdom and New York, NY, USA, 2007.

Ciais, P., Piao, S.-L., Cadule, P., Friedlingstein, P., and Chédin, A.: Variability and recent trends in the African terrestrial carbon balance, Biogeosciences, 6, 1935-1948, 2009, http://www.biogeosciences.net/6/1935/2009/.

Clark, D. A., Piper, S. C., Keeling, C. D., and Clark, D. B.: Tropical rain forest tree growth and atmospheric carbon dynamics linked to interannual temperature variation during 1984-2000, P. Natl. Acad. Sci., 100, 5852-5857, 2003.

Cox, P. M., Betts, R. A., Jones, C. D., Spall, S. A., and Totterdell, I. J.: Acceleration of global warming due to carbon-cycle feedbacks in a coupled climate model, Nature, 408, 184-187, 2000.

Cox, P. M., Betts, R. A., Collins, M., Harris, P. P., Huntingford, C., and Jones, C. D.: Amazonian forest dieback under climatecarbon cycle projections for the 21st century, Theor. Appl. Climatol., 78, 137-156, 2004.

Dufresne, J.-L., Friedlingstein, P. , Berthelot, M., Bopp, L., Ciais, P., Fairhead, L., Le Treut, H., and Monfray, P.: On the magnitude of positive feedback between future climate change and the carbon cycle, Geophys. Res. Lett., 29(10), 1405, doi:10.1029/2001GL013777, 2002.

Dufresne, J. L., Salas y Melia, D., Denvil, S., Tyteca, S., Arzel, O., Bony, S., Braconnot, P., Brockmann, P., Cadule, P., Caubel, A., Chauvin, F., Déqué, M., Douville, H., Fairhead, L., Fichefet, T., Foujols, M.-A., Friedlingstein, P., Grandpeix, J.-Y., Guérémy, J.-F., Hourdin, F., Idelkadi, A., Krinner, G., Lévy, C., Madec, G., Marquet, P., Marti, O., Musat, L., Planton, S., Royer, J.-F., Swingedouw, D., and Voldoire, A.: Simulation du climat récent et futur par les modèles du CNRM et de l'IPSL, La Météorologie, 
55, 45-59, 2007.

Friedlingstein, P., Cox, P., Betts, R., Bopp, L., von Bloh, W., Brovkin, V., Cadule, P., Doney, S., Eby, M., Fung, I., Govindasamy, B., John, J., Jones, C., Joos, F., Kato, T., Kawamiya, M., Knorr, W., Lindsay, K., Matthews, H. D., Raddatz, T., Rayner, P., Reick, C., Roeckner, E., Schnitzler, K.-G., Schnur, R., Strassmann, K., Weaver, A. J., Yoshikawa, C., and Zeng, N.: Climatecarbon cycle feedback analysis: Results from the C4MIP model intercomparison, J. Climate, 19, 3337-3353, 2006.

Golding, N. and Betts, R.: Fire risk in Amazonia due to climate change in the HadCM3 climate model: Potential interactions with deforestation, Glob. Biogeochem. Cy., 22, GB4007, doi:10.1029/2007GB003166, 2008.

Houghton, R. A. and Hackler, J. L.: Carbon Flux to the Atmosphere from Land-Use Changes, in: Trends: A Compendium of Data on Global Change. Carbon Dioxide Information Analysis Center, Oak Ridge National Laboratory, US Department of Energy, Oak Ridge, Tenn., USA, 2002.

Huntingford, C. and Cox, P. M.: An analogue model to derive additional climate change scenarios from existing GCM simulations, Clim. Dynam., 16, 575-586, 2000.

Huntingford, P., Harris, P., Gedney, N., Cox, P. M., Betts, R. A., Marengo, J. A., and Gash, J. H. C.: Using a GCM analogue model to investigate the potential for Amazonian forest dieback, Theor. Appl. Climatol., 78, 177-185, 2004.

Krinner, G., Viovy, N., deNoblet, N., Ogée, J., Polcher, J., Friedlingstein, P., Ciais, P., Sitch, S., and Prentice, I.: A dynamic global vegetation model for studies of the coupled atmospherebiosphere system, Global Biogeochem. Cy., 19(1), GB1015, doi:10.1029/2003GB002199, 2005.

Marland, G., Boden, T. A., and Andres, R. J.: Global, Regional, and National $\mathrm{CO}_{2}$ Emissions, in Trends: A Compendium of Data on Global Change. Carbon Dioxide Information Analysis Center, Oak Ridge National Laboratory, US Department of Energy, Oak Ridge, Tenn., USA, 2005.

Nakićenović, N., Alcamo, J., Davis, G., et al.: IPCC special report on emissions scenarios, Cambridge University Press, Cambridge, United Kingdom and New York, NY, USA, 599 pp., 2000.
Nepstad, D., Lefebvre, P., Lopes da Silva, U., Tomasella, J., Schlesinger, P., Solórzano, L., Moutinho, P., Ray, D., and Guerreira Benito, J.: Amazon drought and its implications for forest flammability and tree growth: a basin-wide analysis, Glob. Change Biol., 10, 704-717, 2004.

Page, S. E., Siegert, F., Rieley, J. O., Boehm, H. D., Jaya, A., and Limin, S.: The amount of carbon released from peat and forest fires in Indonesia during 1997, Nature, 420, 29-30, 2002.

Peylin, P., Bousquet, P., Le Quéré, C., Sitch, S., Friedlingstein, P., McKinley, G., Gruber, N., Rayner, P., and Ciais, P.: Multiple constraints on regional $\mathrm{CO} 2$ flux variations over land and oceans, Global Biogeochem. Cy., 19, GB1011, doi:10.1029/2003GB002214, 2005.

Rödenbeck, C., Houweling, S., Gloor, M., and Heimann, M.: Timedependent atmospheric $\mathrm{CO}_{2}$ inversions based on interannually varying tracer transport, Tellus B, 55, 488-497, 2003.

Saleska, S. R., Didan, K., Huete, A. R., and daRocha, H. R.: Amazon Forests Green-Up During 2005 Drought, Science, 318, p. 612, 2007.

Sitch, S., Huntingford, C., Gedney, N., Levy, P. E., Lomas, M., Piao, S. L., Betts, R., Ciais, P., Cox, P., Friedlingstein, P., Jones, C. D., Prentice, I. C., and Woodward, F. I.: Evaluation of the terrestrial carbon cycle, future plant geography and climate-carbon cycle feedbacks using 5 Dynamic Global Vegetation Models (DGVMs), Global Biogeochem. Cy., 14, 2015-2039, 2008.

vanderWerf, G. R., Randerson, J. T., Collatz, G. J., Giglio, L. Kasibhatla, P. S., Arellano, A. F., Olsen, S. C., and Kasischke, E. S.: Continental-Scale Partitioning of Fire Emissions During the 1997 to 2001 El Ninõ/La Ninã Period, Science, 303, 73-76, 2004.

Zaehle, S., Friedlingstein, P., and Friend, A. D.: Terrestrial nitrogen feedbacks may accelerate future climate change, Geophys. Res. Lett., 37, L01401, doi:10.1029/2009GL041345, 2010. 